Jarmołowicz W., Kuźmar S., Institutional determinants of labor productivity in the selected regions of the European Union, „Ekonomia i Prawo. Economics and Law”, Polszakiewicz B., Boehlke J. (ed.), Vol. 14, No. 3/2015, pp. 459-478. DOI: http://dx.doi.org/10.12775/EiP.2015.030.

\author{
WACŁAW JARMOŁOWICZ*, SŁAWOMIR KUŹMAR ${ }^{* *}$
}

\title{
INSTITUTIONAL DETERMINANTS OF LABOR PRODUCTIVITY IN THE SELECTED REGIONS OF THE EUROPEAN UNION ${ }^{\diamond}$
}

\author{
SUMMARY
}

Facing the growing importance of institutions as a vital, or according to some, even a key determinant of economic growth and development, the authors of this study attempt to define and determine basic relations and mechanisms by which the institutional environment affects labor productivity. In addition, an analysis of institutions diversity and labor productivity was carried out in selected regions of the European Union. The findings of the analyses prompt to draw a conclusion that "good" institutional solutions have a significant impact on the development of labor productivity also at regional level by protecting property rights, lowering transaction costs, stimulating competition and improving the efficient functioning of the market mechanism.

Keywords: formal institutions; informal institutions; labor productivity

JEL Classification: E02; O43

"Wacław Jarmołowicz, WSB Schools of Banking, Faculty of Finance and Banking, Institute of Economic Sciences, al. Niepodległości 2, 61-874 Poznań, Poland, phone: +48 616553 333, e-mail: waclaw.jarmolowicz@ue.poznan.pl (corresponding author).

"Sławomir Kuźmar, Poznań University of Economics, Faculty of Economics, Department of Macroeconomics and National Economy Research, al. Niepodległości 10, 61-875 Poznań, Poland, phone: +48 618543 023, e-mail: slawomir.kuzmar@ue.poznan.pl.

$\checkmark$ The article was funded by National Science Centre (2014/13/N/HS4/02061). 


\section{INTRODUCTION}

Issues relating to the importance of the institutional environment (institutions) $)^{1}$ for broadly understood functioning of economy or its more specific perception relating to various areas or aspects including, among others, labor productivity, are still relatively new and constitute a constantly growing economic analyses trend. Despite the fact that sociologists and unorthodox economists have been dealing with issues relating to the institutional environment ${ }^{2}$ for over one hundred years, the relations between the institutions and the real economy were usually disregarded by mainstream economists, in particular, these issues were almost totally ignored by economists dealing with the theory of economic growth. The neoclassical theory of economic growth, apart from labor, regarded capital accumulation ${ }^{3}$ in particular as a key factor contributing to growth. In subsequent years, an approach proposed by R. Solow was developed and expanded, also giving importance to such factors as: innovation ${ }^{4}$, human capital ${ }^{5}$, economies of scale ${ }^{6}$ and geography. However, long-lasting differences in levels of development of particular countries and regions, which could not be explained by traditional factors and models of growth, encouraged the search for new approaches, includ-

1 The authors would like to stress the fact that the institutions in this research are understood exclusively as rules, norms, regulations, codified in the rules of law or of informal character, specifying the behavior of economic agents in society and economy (more specific definitions will be presented later in this study). Emphasising this fact is significant, since in Polish literature, the term "institution" is also interpreted as an organisation or organisational structure. These are also issues worthy of attention, although they are beyond the scope of this article.

${ }^{2}$ Issues concerning the importance of institutions in the sociological context were discussed, among others, by F. Tönnies'a - 1887 or M. Weber 1920, 1921 (A. Rodríguez-Pose, Do institutions matter for regional development?, "Regional Studies", Vol. 47, No. 7/2013, p. 1035). Moreover, T. Veblen is considered to be a precursor of institutional economics (as one of the branches of the unorthodox economy). His first work on the institutional environment of the economy dates back to 1899 (W. Stankiewicz, Ekonomia instytucjonalna. Narodziny i rozwój, Wydawnictwo Biura Badań Strategicznych Wyższej Szkoły Biznesu i Administracji, Warszawa 2004, p. 34 and other).

${ }^{3}$ R.M. Solow, A contribution to the theory of economic growth, "Quarterly Journal of Economics", Vol. 70, No. 1/1956, pp. 65-94.

${ }^{4}$ S.M. Romer, Increasing returns and long-run growth, "Journal of Political Economy", Vol. 94, No. 5/1986, pp. 1002-1037.

5 R. Lucas, On the mechanics of economic development, "Journal of Monetary Economics", Vol. 22, No. 1/1988, pp. 3-42.

${ }^{6}$ P.R. Krugman, Increasing Returns and Economic Geography, "Journal of Political Economy", Vol. 99, No. 3/1991, pp. 483-499; P.R. Krugman, Geography and Trade, Cambridge MIT Press, Cambridge M.A, 1991. 
ing potential determinants affecting economic growth. Consequently, in the analyses of the causes and changes in the level and dynamics of economic growth institutional environment of the economy appeared more frequently as an important factor contributing to economic growth, and valued equally, and sometimes even beyond the traditional determinants of growth ${ }^{7}$.

The above mentioned differences in the levels of development and growth were particularly evident in the second half of the 90s, including the regions of the European Union, which was a sign of the increasing diversity of labor productivity ${ }^{8}$ in the observed area both among the regions belonging to the so-called old and new member states ${ }^{9}$. At the same time, these differences could be explained only to a limited extent by the differentiation observed in the field of the so-called traditional growth factors (i.e. accumulation of physical and human capital, technological progress, openness and competitiveness of economies, infrastructure and spatial conditions, etc.). As a result, attention was paid, among others, also to institutional differences occurring in different countries and regions of the EU ${ }^{10}$. Taking into account the above state of affairs, the objective of the present study is an attempt to clarify and determine the significance of basic dependencies and mechanisms

7 Ibidem; D. Acemoglu, S. Johnson, J.A. Robinson, The colonial origins of comparative development: an empirical investigation, "American Economic Review", Vol. 91, No. 5/2001, pp. 13691401; D. Rodrik, F. Subramanian, F. Trebbi, Institutions rule: the primacy of institutions over geography and integration in economic development, "Journal of Economic Growth", Vol. 9, No. 2/2004, pp. 131-165; D. Acemoglu, S. Johnson, J.A. Robinson, Institutions as a fundamental cause of long-run growth, "Handbook of Economic Growth", Vol. 1, Part A/2005, pp. 385472; D. Acemoglu, J.A. Robinson, De facto political power and institutional persistence, "American Economic Review”, Vol. 96, No. 2/2006, pp. 325-330.

${ }^{8}$ The assessment of the state and development prospects of given countries and regions is usually done through the analyses of the level and growth of GDP per capita, still, according to the authors, labor productivity constitutes a good and more in-depth measure of the use of resources, assessing simultaneously the current level of development of given economy and its prospects of growth.. This measure juxtaposes the level of use of labor resources of the given economy (expressed in terms of employment level, or the total number of hours worked) with the size of the product generated by this resource. Therefore, this combination allows to determine the level of efficiency of available resources, and thus corresponds with a potential for development of particular economy (W. Jarmołowicz, S. Kuźmar, Efektywnośc gospodarowania zasobami pracy w regionie - na przyktadzie województwa wielkopolskiego w latach 2000-2012, Studia i Prace WNEiZ US, Vol. 35, No. 2/2014, p. 333).

${ }^{9}$ C. Ertur, J. Le Gallo, C. Baumont, The European regional convergence process, 1980-1995: Do spatial regimes and spatial dependence matter?, "International Regional Science Review", Vol. 29, No. 1/2006, pp. 3-34; S. Magrini, Regional (Di)Convergence, Handbook of Regional and Urban Economics, Amsterdam 2004, pp. 2741-2796; P. Monfort, Convergence of EU regions. Measures and evolution, Directorate-General for Regional Policy Working Paper, No. 01/2008.

${ }^{10}$ A. Rodríguez-Pose, op. cit., p. 1036. 
by which the institutional environment affects productivity along with examining the diversity of institutions and labor productivity in the selected regions of the European Union.

Thus, starting with an attempt to determine a contemporary definition of the institution in terms of both formal and informal aspects, the paper presents potential dependencies and mechanisms through which institutions can affect labor productivity. In addition, in a further section of the paper, the analysis and assessment of the diversity of institutions and the level of labor productivity in selected regions of the UE will be carried out. The paper ends with a short summary with an indication of the most important implications drawn from the conducted analyses.

\section{MODERN UNDERSTANDING OF INSTITUTIONS}

Despite a growing popularity of importance or the role of institutions in the economy, their universally accepted definition does not really exist. In the economic literature, especially in the context of considerations of the new institutional economics, there are many divergent ways of understanding this concept, although most of them share a common assumption of the fact that they are, broadly speaking, a set of formal or informal rules that determine the behavior of people as individual economic entities. At the same time, one of the most-frequently quoted definition of institutions in economic terms is the one proposed by D. North, according to whom institutions are "the rules of the game" functioning in society, which more formally means that they constitute restrictions defined and shaped by people and which affect their interactions. According to this approach, the institutions structure the stimuli and interpersonal relations of political, social or economic nature ${ }^{11}$.

In accordance with D. North's definition, institutions can also be divided into formal (hard) and informal (soft). The first group consists of universal and transferable rules laid down in the law (constitution, statutes, ordinances, statutes). Formal institutions are therefore subject to conscious and rational changes, usually of a legislative nature. It is worth noting that because of the relative ease with which they can be identified, they constitute formal rules or systems of rules that control or restrict human behaviors. On the other hand, informal institutions comprise spontaneous and unwritten norms of human behaviors, guided by self-interest. These institutions include

${ }^{11}$ C.D. North, Institutions, Institutional Change, and Economic Performance, Cambridge University Press, New York 1990, p. 3. 
habits, beliefs, taboos, myths, ethical standards, mutual cooperation, trust, etc. In the light of the above findings, the goal of formal institutions, among others, is to facilitate transactions between individual economic entities, whereas informal institutions expand the possibilities of conducting these transactions, due to the fact that they increase or modify the scope of application of these formal rules. Moreover, D. North points to the fact that formal institutions have a much more changeable nature than informal institutions. The formal rules may in fact be changed in a relatively short period of time, eg. as a result of political or judicial decision, while informal institutions as rooted in customs, traditions, or self-imposed rules of conduct, being more resistant to the applied policy, usually adopt much more durable character ${ }^{12}$.

However, it has to be stressed that the traditional classification of institutions into formal and informal ones is currently more often abandoned in favour of, among others, division into internal and external institutions. The method of recognizing certain institutions as external or internal depends on who imposes sanctions on violators of certain principles or rules of conduct. For example, if sanctions are introduced by the state, the institutions they relate to are "external", whereas "internal" institutions are the ones whose observance is sanctioned by various groups of the society, for example certain communities (including secular and religious organizations or associations), or individually by the participants of economic life, acting on the basis of the so-called norms of reciprocity ${ }^{13}$.

In assessing relations between the institutions and economy, their division into institutions of political and economic, or social character seems to be equally important. Thus, for example D. Acemoglu et. al., define economic institutions as a set of incentives, stimuli and restrictions regarding economic entities, which affect the economic results they achieve, stressing that economic institutions shape the structure of economic stimuli occurring in a given society, because without appropriate protection of property rights, market participants would have no incentive to accumulate physical and human capital, or to adapt more efficient technologies and processes of production organization. In turn, political institutions also determine restrictions and incentives, but in this case they concern political sphere. According to the authors, political institutions allows the allocation of political power de jure and determine the functioning of economic institutions. In this perspective, institutions also have a hierarchical structure, within which political institutions domi-

12 C.D. North, op. cit., p. 6, 43, 83.

13 S. Vogit, How (Not) to Measure Institutions, "Joint Discussion Paper Series in Economics", No. $37 / 2009$, p. 8. 
nate economic ones ${ }^{14}$. Analyzing historical significance of institutions, J. D. Acemoglu and J. A. Robinson also divide institutions into exploitative institutions (called extractive Institutions), when a small group of those in power exploit and take advantage of the rest of society and inclusive institutions, which provide access to exercise power to wider circles, which also substantially reduces or even makes it impossible to exploit society as a whole ${ }^{15}$.

\section{THE IMPACT OF INSTITUTIONS ON ECONOMIC GROWTH - THEORETICAL APPROACH}

Issues related to the assessment of relations between institutions and growth, or broadly speaking, economic development, presently constitute some of the most current economic issues which are dealt with by institutional economists, as well as theorists of economic growth ${ }^{16}$. Despite the agreement relating to the existence of a certain and positive relation between developed and well-functioning institutions and economic growth, the economists are not yet able to clearly identify the fundamental factors and the mechanisms responsible for this relation ${ }^{17}$. Moreover, there are also doubts about the direction of this relation, and an increase in the importance of such views that is the improvement of the economic situation which facilitates the creation of good institutions ${ }^{18}$.

In order to determine the potential mechanisms and channels of the impact of institutional environment on the functioning of the economy, it should also be stressed that not only the existence of specific institutions is of importance, but also the level of their development and quality. It affects investment decisions, the kind of production organization, and is crucial for ways of distributing the benefits of their investment projects and development strategies. Thus, the assessment of "welfare" of existing institutions and the search for an answer to the question about characteristics of "good" insti-

${ }^{14}$ D. Acemoglu, S. Johnson, J.A. Robinson, Institutions..., op. cit., pp. 386-387.

15 D. Acemoglu, J.A. Robinson, Why Nations Fail, Crown Business, New York: Cambridge University Press, 2012.

${ }^{16}$ E. Ostrom, Challenges and Growth: The Development of the Interdisciplinary Field of Institutional Analysis, "Journal of Institutional Economics", Vol. 3, No. 03/2007, pp. 239-264.

${ }^{17}$ E. Valeriani, S. Peluso, The Impact Of Institutional Quality On Economic Growth And Development: An Empirical Study, "Journal of Knowledge Management, Economics and Information Technology”, No. 6/2011, pp. 1-25.

18 A. Chong, C. Calderon, Causality and Feedback Between Institutional Measures and Economic Growth, "Economics and Politics", Vol. 12, No. 1/2000, pp. 69-81. 
tutions is also of significant importance. For example, it is believed that good institutions should be distinguished by certain characteristics some of which are the following ${ }^{19}$ :

- They should enable the transfer of information on markets including goods, services and business entities operating among market participants. This is due to the fact that they have a significant impact on the creation, collection, analysis, dissemination or limiting specific information and knowledge. An efficient and smooth flow of information helps market operators to identify market partners and determine potential investment potential, and at the same time verify their credibility.

- They should have an impact on defining and protecting property rights and contracts concluded between economic operators. The rights to own property and have an income and the possibility of their protection are in fact crucial to the processes of development and economic growth.

- In addition, they should have an impact on the increase in the scope of competition, which in turn can result in the development of innovation and improve the efficiency of markets functioning.

Therefore, from an economic point of view "good" institutions are those that contribute to ensure equal access to the market and macroeconomic stability and provide an adequate guarantee of the rights to the creation and ownership of private property ${ }^{20}$. On the other hand, from yet another perspective, A. Rodriguez-Pose points out that successful institutions should facilitate a voluntary and mutual exchange of benefits and be "adequate, reliable and efficient" ${ }^{21}$.

One of the most frequently mentioned mechanisms by which good institutions contribute to the improvement of the economic situation is their impact on the reduction of transaction costs ${ }^{22}$. It is done by limiting uncertainty

19 World Bank, World Development Report 2002: Building Institutions for Markets, Oxford University Press, New York 2002, p. 8.

20 D. Miłaszewicz, Jakość instytucji a wzrost gospodarczy, "Studia i Prace Wydziału Nauk Ekonomicznych i Zarządzania”, No. 19/2011, p. 15.

${ }^{21}$ A., Rodrigez-Pose, op. cit.

22 These costs can be divided into economic and political ones. The economic costs can further be divided into market and managerial costs. Within market costs, among others, the following can be distinguished: costs of search and information processing (the cost of preparing the contract) negotiations, and decision (the cost of the contract) as well as the monitoring and enforcement of the contract. Managerial costs, in turn, include the costs connected with initiating, conduct and changes in business operations. The presence of the latter type of transaction costs, political ones concerns the fact that the economic transaction costs can only occur in the context of the existence of certain political arrangements (institutional ones). It implies the need for functioning of regional and national organizations and related public goods. 
that this action is possible, among others, when specific scenarios of conduct exist and patterns of interactions are created. Furthermore, the structure of an institution that promotes the reduction in transaction costs, also allowing an increase in the efficiency of markets operating.

Reduction in transaction costs is possible, on the one hand, thanks to the functioning of appropriate institutions, constituting a guarantee for the contracts and obligations, including those that settle disputes concerning commercial law or restrict monopolistic practices. On the other hand, it may be a consequence of specific relations and social attitudes that may result in reductions in costs of acquiring and processing information. In addition, the relevant institutions allow the expansion of the potential market, facilitate the identification and sanctioning opportunistic practices and accelerate the transmission of information on good practices, thereby facilitating their implementation and diffusion. On the other hand, habits and shared values allow to take collective action and coordinate individual decisions, leading to economies of scale and the improvement of the efficiency of the companies ${ }^{23}$.

Apart from the direct impact of the institutional environment on the reduction of transaction costs, the body of literature on this subject also points out to the mechanism by which well-functioning institutions contribute to the growth of innovation and entrepreneurship. Well-functioning institutions set and ensure the right to property and its protection, causing the occurrence of positive stimuli to accumulate physical and human capital, or to adapt more efficient technologies and processes, organization of production, thus becoming one of the key factors or pillars of entrepreneurship ${ }^{24}$. Still, other approaches indicate that the institutions positively affect the economy by providing public goods and reducing negative externalities ${ }^{25}$, enhance

Political transaction costs include the costs of development, maintenance and change of formal and informal public organizations (the judiciary, the central and local government administration) (A. Golejewska, Kapitat ludzki, innowacje i instytucje a konkurencyjność regionów Europy Środkowej i Wschodniej (Human capital, innovations and institutions versus the competitiveness of regions in Central and Eastern Europe), "Zeszyty Natolińskie”, No. 49/2013, p. 25).

${ }^{23}$ D. Miłaszewicz, op. cit., p. 14.

${ }^{24} \mathrm{~F}$. Sautet, The role of institutions in entrepreneurship: implications for development policy, Mercatus Policy Series, Policy primer No. 1/2005, pp. 6-7; W.J. Baumol, Entrepreneurship: productive, unproductive and destructive, "Journal of Political Economy", Vol. 98, No. 5/1990, pp. 893-921.

${ }_{25}$ W. Streeck, On the institutional conditions of diversified quality production, [in:] E. Metzner, K.W. Streec (eds), Beyond Keynesianism: Socio-Economics of Production and Full Employment, Elgar Publishing, Aldershot 1991, pp. 21-61. 
the transparency of the economy ${ }^{26}$ or help to increase the efficiency of the labor markets ${ }^{27}$.

The issue concerning the relations between formal and informal institutions and their impact on the functioning of economy seems to be of vital importance for the purpose of the analysis carried out in this study. Thus, as indicated by, among others, A. Amin, a prerequisite of the effectiveness of the institutional environment in shaping the development of given regions, is the existence of some kind of balance between formal and informal institutions $^{28}$. Formal institutions provide significant stimuli for entrepreneurial activities through their impact on the reduction in the level of risk, uncertainty and corruption ${ }^{29}$. On the other hand, informal institutions can provide, under certain conditions, sort of substitutes for malfunctioning formal institutions, significantly reduce transaction costs, promote concentrating economic activity in certain locations and also strengthen local economic interdependence ${ }^{30}$.

\section{INSTITUTIONS VERSUS LABOR PRODUCTIVITY IN EU REGIONS}

An empirical analysis of the role and significance of institutions for the phenomena and economic processes is a challenging task, which results from the fact that not only the occurrence of complications associated with their definition but also the their measurement. Therefore, a complex nature of this category also makes it very difficult or even impossible to easily quantify the institutions in one or even a few measures. Still, despite these methodological problems, for several years attempts have been made in this respect. More or less detailed or general and synthetic measures have been created to be applied to the institutions in certain countries ${ }^{31}$.

However, it should also be noted that these are often relatively simplistic approaches which only to a limited extent reflect the very presence

${ }^{26}$ M. Storper, Society, community and economic development, "Studies in Comparative International Development", No. 39/2005, pp. 30-57.

27 S. Kuźmar, M. Pilc, The Impact of Labor Market Institutions on Labor Market Performance in Transition Countries, "Ekonomista", No. 1/2015, pp. 43-66.

28 A. Amin, An institutionalist perspective on regional development, "International Journal of Urban and Regional Research", Vol. 23, No. 2/1999, pp. 365-378.

29 A. Chakravarti, Aid, Institutions and Development. New Approaches to Growth, Governance and Poverty, Edward Elgar Publishing, Cheltenham, UK, Northampton, MA USA 2005, p. 25.

30 A. Amin, N.,Thrift, Globalization, Institutions and Regional Development in Europe, Oxford University Press, Oxford 1994, p. 230.

${ }^{31}$ K. Szarzec, Państwo w gospodarce, Wydawnictwo PWN, Warszawa 2013, pp. 256-257. 
as well as a certain quality of the institutions. Even more selective and rare are the attempts to identify and assess the type and quality of institutions occurring within particular regions. One of the best known research of this type is for example the analysis commissioned by the European Commission and carried out by a team from the Quality of Government Institute at the University of Gothenburg ${ }^{32}$. As part of the work undertaken here (conducted for the first time in 2010) a synthetic index (consisting of four sub-indicators) EQI (called. The European Quality of Government Index), reflecting the nature of the institutions in the regions of the EU of 28 member States. Thus, the regions were delineated on the basis of the classification of nomenclature of territorial units for statistics - NUTS level 2 (eg. the level in case of Poland is an equivalent to voivodeships). In order to construct this synthetic index (based, in particular, on the method applied by the World Bank ${ }^{33}$ ), sub-indicators were used, such as levels of corruption, the rule of law, the bureaucratic effectiveness, and government voice and accountability). In order to ensure the comparability of the analyzed indicators, their values have been standardized (according to their regular distribution), and thus their value on the scale is approx. -2.5 to 2 . The above indicators are also used in this study.

For the purpose of the study, the authors assume that the level of gross added value per hour worked, expressed in fixed prices in Euro from 2005 is an indicator of labor productivity in particular regions of the EU. The data necessary to calculate those values were obtained from the European Regional Database created by Cambridge Econometrics.

Therefore, with the use of indicators and figures mentioned above, figure 1 shows the development of the combined indicator of institutions and its minimum and maximum values in particular regions of a given country.

${ }^{32}$ N. Charron et al., Measuring the quality of government and subnational variation, Quality of Government Institute, Department of Political Science, University of Gothenburg Sweden, Gothenburg 2010.

${ }^{33}$ It is method used to create indicators called Worldwide Governance Indicators, http://info.worldbank.org/governance/wgi/index.aspx\#doc. 


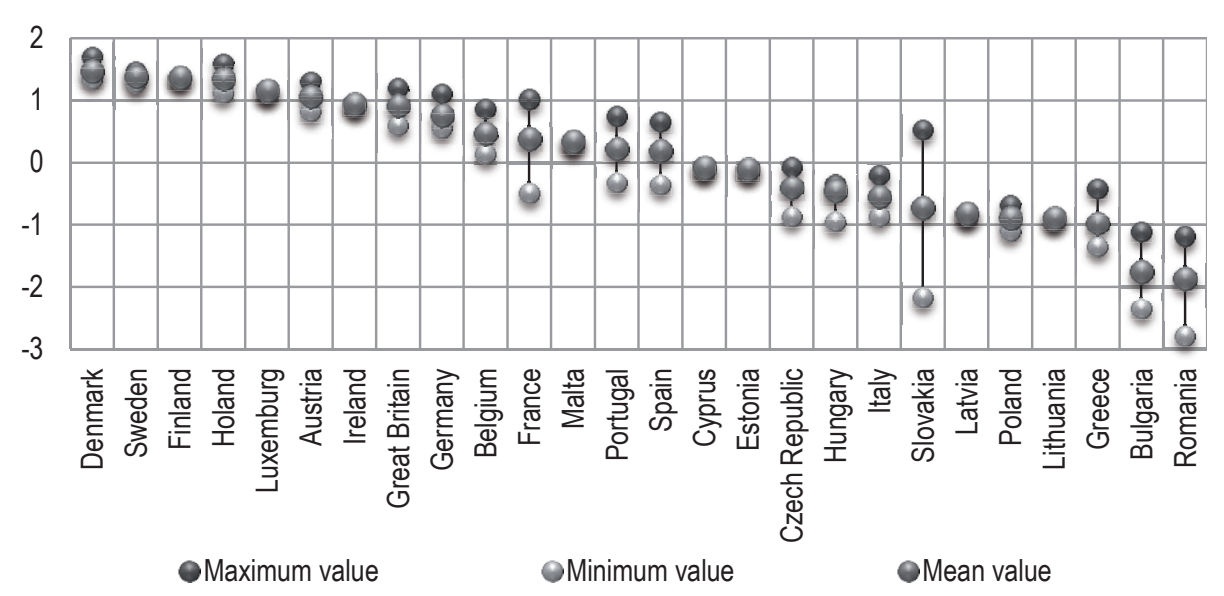

Figure 1. The formation of the EQI in countries and regions of the EU in 2009

Source: own materials based on selected data: Quality of Government Institute 2010, http://qog.pol.gu.se/data/datadownloads/qogeuregionaldata (03.08.2015).

The figure shows that the countries with the highest quality political institutions are Denmark, Sweden, Finland, the Netherlands and Luxembourg. In turn, the worst rated institutions are the ones located in Romania, Bulgaria, Greece, Lithuania and Poland. Noteworthy are also significant differences in terms of interregional differentiation of institutions in particular countries. For example, in the countries where institutions are evaluated highly, significant interregional differences are not observed. However, they are particularly important in the countries where institutions get lower scores, and also in Italy, where the difference between regions characterized by the highest and lowest assessment scores, were the largest among all the analyzed countries.

The values of the applied quality indicators of the institutional environment in the countries concerned and their maximum and minimum values in each region are presented in table 1 and 2. 
Table 1. Selected political institutions in the EU in the light of the analyzed sub-indicators in 2009

\begin{tabular}{|c|c|c|c|c|c|c|c|}
\hline \multirow{2}{*}{ COUNTRIES } & \multicolumn{3}{|c|}{ CORRUPTION } & \multirow{2}{*}{ COUNTRIES } & \multicolumn{3}{|c|}{ RULE OF LAW } \\
\hline & MIN & $\operatorname{MAX}$ & MEAN & & MIN & MAX & MEAN \\
\hline Finland & 1.69 & 1.69 & 1.69 & Austria & 1.16 & 1.56 & 1.40 \\
\hline Denmark & 1.48 & 1.86 & 1.68 & Denmark & 1.12 & 1.62 & 1.37 \\
\hline Holland & 1.28 & 1.72 & 1.53 & Sweden & 1.27 & 1.45 & 1.32 \\
\hline Sweden & 1.35 & 1.64 & 1.50 & Finland & 1.29 & 1.29 & 1.29 \\
\hline Luxembourg & 1.27 & 1.27 & 1.27 & Luxembourg & 1.20 & 1.20 & 1.20 \\
\hline Austria & 0.81 & 1.28 & 1.04 & Holland & 0.99 & 1.59 & 1.19 \\
\hline Great Britain. & 0.73 & 1.20 & 0.95 & Ireland & 1.08 & 1.08 & 1.08 \\
\hline Ireland & 0.92 & 0.92 & 0.92 & Great Britain & 0.56 & 1.30 & 1.01 \\
\hline Germany & 0.51 & 1.18 & 0.91 & Malta & 0.83 & 0.83 & 0.83 \\
\hline Belgium & 0.20 & 0.57 & 0.35 & Germany & 0.28 & 1.03 & 0.52 \\
\hline France & -0.60 & 0.92 & 0.34 & France & -0.29 & 1.03 & 0.47 \\
\hline Portugal & -0.34 & 0.97 & 0.34 & Belgium & -0.11 & 1.04 & 0.37 \\
\hline Spain & -0.16 & 0.61 & 0.20 & Spain & -0.49 & 0.71 & 0.24 \\
\hline Cyprus & -0.01 & -0.01 & -0.01 & Portugal & -0.46 & 0.71 & 0.10 \\
\hline Malta & -0.04 & -0.04 & -0.04 & Estonia & -0.04 & -0.04 & $-0,04$ \\
\hline Estonia & -0.14 & -0.14 & -0.14 & Cyprus & -0.08 & -0.08 & -0.08 \\
\hline Hungary & -1.19 & -0.29 & -0.52 & Hungary & -1.13 & -0.08 & -0.27 \\
\hline Slovenia & -0.91 & -0.12 & -0.56 & Czech Republic & -1.00 & -0.09 & -0.40 \\
\hline Poland & -1.20 & -0.57 & -0.82 & Latvia & -0.58 & -0.58 & -0.58 \\
\hline Czech Republic & -1.29 & -0.50 & -0.89 & Greece & -1.08 & -0.11 & -0.62 \\
\hline Italy & -2.63 & 0.38 & -0.92 & Slovenia & -1.09 & -0.28 & -0.69 \\
\hline Latvia & -0.98 & -0.98 & -0.98 & Italy & -2.04 & 0.23 & -0.81 \\
\hline Lithuania & -1.12 & -1.12 & -1.12 & Lithuania & -0.82 & -0.82 & -0.82 \\
\hline Greece & -1.43 & -1.08 & -1.25 & Poland & -1.14 & -0.55 & -0.93 \\
\hline Romania & -2.78 & -0.69 & -1.46 & Romania & -2.80 & -1.14 & -1.87 \\
\hline Bulgaria & -2.18 & -1.05 & -1.52 & Bulgaria & -3.32 & -1.17 & -2.03 \\
\hline
\end{tabular}

Source: own materials on the basis of the selected data: Quality of Government Institute 2010, http://qog.pol.gu.se/ data/datadownloads/qogeuregionaldata (03.08.2015). 
Table 2. Selected political institutions in the EU member states in the light of the analyzed sub-indicators in 2009

\begin{tabular}{|c|c|c|c|c|c|c|c|}
\hline \multirow{2}{*}{ COUNTRIES } & \multicolumn{3}{|c|}{ BUREAUCRATIC EFFECTIVENESS } & \multirow{2}{*}{ COUNTRIES } & \multicolumn{3}{|c|}{$\begin{array}{l}\text { GOVERNMENT VOICE } \\
\text { AND ACCOUNTABILITY }\end{array}$} \\
\hline & MIN & MAX & MEAN & & MIN & MAX & MEAN \\
\hline Denmark & 1.38 & 1.87 & 1.56 & Holland & 1.16 & 1.58 & 1.47 \\
\hline Sweden & 1.13 & 1.37 & 1.25 & Sweden & 1.33 & 1.58 & 1.44 \\
\hline Finland & 1.22 & 1.22 & 1.22 & Luxembourg & 1.34 & 1.34 & 1.34 \\
\hline Holland & 0.83 & 1.46 & 1.14 & Denmark & 1.01 & 1.54 & 1.26 \\
\hline Great Britain & 0.51 & 1.35 & 0.94 & Finland & 1.25 & 1.25 & 1.25 \\
\hline Austria & 0.60 & 1.16 & 0.90 & Ireland & 1.00 & 1.00 & 1.00 \\
\hline Germany & 0.18 & 1.63 & 0.82 & Belgium & 0.87 & 0.97 & 0.90 \\
\hline Luxembourg & 0.76 & 0.76 & 0.76 & Austria & 0.39 & 1.42 & 0.88 \\
\hline Ireland & 0.71 & 0.71 & 0.71 & Germany & 0.38 & 0.89 & 0.76 \\
\hline France & -0.80 & 1.07 & 0.45 & Great Britain & 0.09 & 1.29 & 0.75 \\
\hline Belgium & -0.40 & 0.96 & 0.20 & Portugal & -0.18 & 1.15 & 0.39 \\
\hline Malta & 0.19 & 0.19 & 0.19 & Malta & 0.32 & 0.32 & 0.32 \\
\hline Cyprus & 0.17 & 0.17 & 0.17 & France & -1.13 & 1.17 & 0.25 \\
\hline Portugal & -0.29 & 0.35 & 0.05 & Spain & -0.59 & 1.12 & 0.25 \\
\hline Spain & -0.87 & 0.53 & 0.03 & Estonia & -0.31 & -0.31 & -0.31 \\
\hline Estonia & 0.03 & 0.03 & 0.03 & Italy & -1.96 & 0.91 & -0.32 \\
\hline Czech Republic & -0.29 & 0.44 & 0.03 & Czech Republic & -1.34 & 0.30 & -0.36 \\
\hline Slovenia & -0.62 & -0.06 & -0.37 & Hungary & -0.66 & -0.22 & -0.40 \\
\hline Hungary & -0.81 & -0.54 & -0.66 & Cyprus & -0.45 & -0.45 & -0.45 \\
\hline Lithuania & -0.73 & -0.73 & -0.73 & Slovenia & -1.10 & -0.34 & -0.59 \\
\hline Latvia & -0.85 & -0.85 & -0.85 & Greece & -1.59 & -0.11 & -0.74 \\
\hline Italy & -2.40 & 0.80 & -0.86 & Poland & -1.34 & -0.43 & -0.91 \\
\hline Poland & -1.22 & -0.63 & -0.92 & Latvia & -0.91 & -0.91 & -0.91 \\
\hline Greece & -1.78 & 0.23 & -1.32 & Lithuania & -0.95 & -0.95 & -0.95 \\
\hline Bulgaria & -2.41 & -0.62 & -1.56 & Bulgaria & -3.13 & -1.36 & -1.94 \\
\hline Romania & -2.64 & -1.31 & -1.91 & Romania & -2.92 & -1.42 & -2.25 \\
\hline
\end{tabular}

Source: own materials based on selected data: Quality of Government Institute 2010, http://qog.pol.gu.se/data/datadownloads/qogeuregionaldata (03.08.2015). 
As the figures in the tables above indicate, just like in case of the synthetic indicator, also particular and sub-indicators of institutions relating to their quality, are top rated in Denmark, Scandinavian countries and the Benelux countries. On the other hand, the lowest rated institutions are in the new EU member states, Greece and Italy.

More visual and general presentation and assessment of institutions in the various regions of the European Union, is shown in picture 1 significant differences between southern and northern regions of Italy, and also in the regions of France, Bulgaria and Romania are striking.
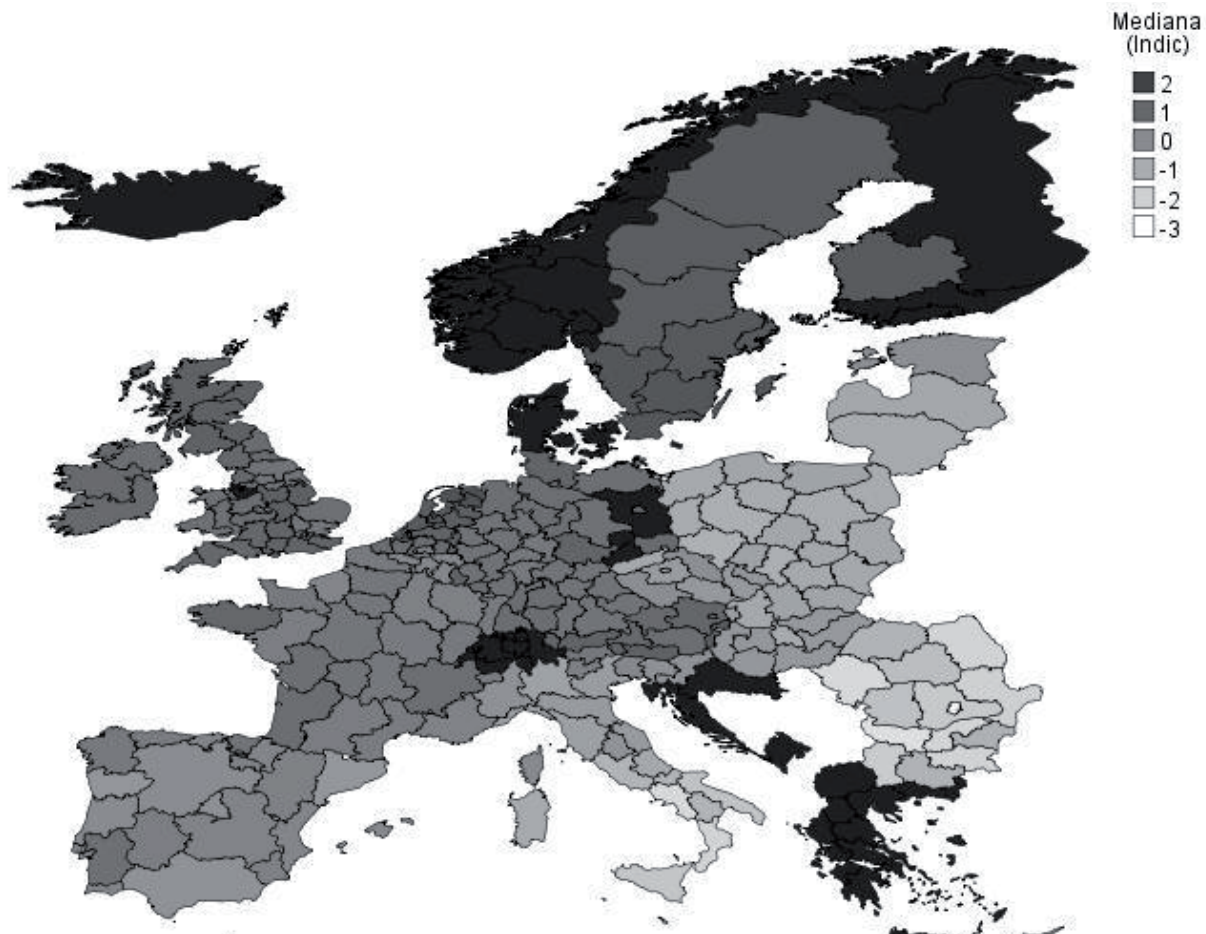

Picture 1. Values of EQI indicator in the analyzed EU member states

Source: own materials based on selected data: Quality of Government Institute 2010, http://qog.pol.gu.se/data/datadownloads/qogeuregionaldata (03.08.2015).

Since there are substantial differences in the examined institutions in various regions of the European Union, it seems to be crucial to pose a question whether these differences can be attributed to economic results achieved by the respective regions. In order to answer this question, the values of hour- 
ly labor productivity in the 243 regions $^{34}$ of the EU in the years 1995-2012 were analyzed (table 3).

Table 3. Hourly productivity in the countries and regions of the EU in the years 1995-2012 (in fixed EUR prices in 2005)

\begin{tabular}{|c|c|c|c|c|}
\hline YEARS & MINIMUM LEVEL & MAXIMUM LEVEL & MEAN LeVEL & STANDARD DEVIATION \\
\hline 1995 & 1.54 & 49.53 & 22.98 & 10.99 \\
\hline 1996 & 1.60 & 50.68 & 23.31 & 11.07 \\
\hline 1997 & 1.50 & 52.08 & 23.82 & 11.26 \\
\hline 1998 & 1.45 & 53.74 & 24.12 & 11.40 \\
\hline 1999 & 1.51 & 54.31 & 24.45 & 11.49 \\
\hline 2000 & 1.51 & 55.86 & 25.18 & 11.89 \\
\hline 2001 & 1.66 & 53.86 & 25.59 & 11.99 \\
\hline 2002 & 2.11 & 55.80 & 26.06 & 12.12 \\
\hline 2003 & 2.15 & 57.65 & 26.57 & 12.25 \\
\hline 2004 & 2.52 & 58.26 & 27.09 & 12.44 \\
\hline 2005 & 2.51 & 59.69 & 27.45 & 12.69 \\
\hline 2006 & 2.64 & 62.55 & 28.20 & 13.01 \\
\hline 2007 & 2.77 & 62.57 & 28.54 & 13.08 \\
\hline 2008 & 2.69 & 72.82 & 28.59 & 13.16 \\
\hline 2009 & 2.67 & 65.42 & 28.03 & 12.68 \\
\hline 2010 & 2.84 & 69.83 & 28.62 & 13.06 \\
\hline 2011 & 2.64 & 73.51 & 29.09 & 13.28 \\
\hline 2012 & 2.77 & 71.17 & 29.08 & 13.14 \\
\hline
\end{tabular}

Source: own materials based on selected data: European Regional Database, Cambridge Econometrics, http://www.camecon.com/SubNational/SubNationalEurope/RegionalDatabase.aspx (03.08.2015).

The conclusions drawn are that, as in case of institutions, the analyzed group of regions is characterized by great differentiation in terms of hourly labor productivity. However, at the same time some positive trends manifested in the increase in the average level of labor productivity and a significant increase in performance in the regions with the lowest may be observed. Furthermore, significant differentiation in labor productivity in the analyzed

${ }^{34}$ In order to ensure comparability of data, the analysis does not cover the capital regions of the examined countries. 
group is also reflected in high values of the coefficient of variation ${ }^{35}$ and Gini coefficient ${ }^{36}$ presented in figure 3 . It should also be noted that differences in hourly productivity throughout the analyzed period were relatively stable with only a slight decrease.

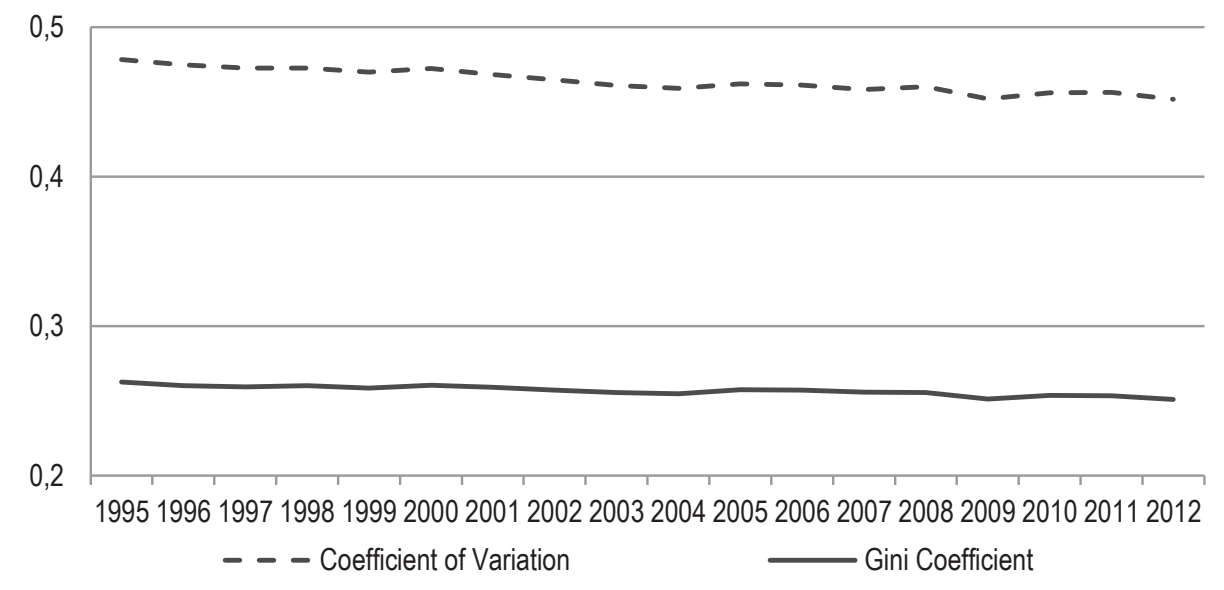

Figure 3. Values of differentiation in labor productivity at regional level in the EU

Source: own materials based on selected data: European Regional Database, Cambridge Econometrics, http://www.camecon.com/SubNational/SubNationalEurope/RegionalDatabase.aspx.

Figure 4 shows the interdependence between the analyzed institutions and the average hourly labor productivity in 1995-2008. The presented data show that the regions with higher rated institutions, also rank higher as for hourly labor productivity. High value of the correlation coefficient ${ }^{37}$, which amounted to 0.75 also proves the mutual relation between those two figures.

${ }^{35}$ In order to ensure data comparability, the capital regions of the analyzed countries were not examined.

${ }^{36}$ The value of concentration ratio was calculated using the formula for Lorentz curve: $\frac{n+1}{n}-\frac{2 \sum_{1}^{n}(n+1-i) x_{i}}{n \sum_{1}^{n} x_{i}}$.

37 Calculated in accordance with the Pearson formula of correlation between average hourly labor productivity in 1995-2008 and the values of the global QoG index. 


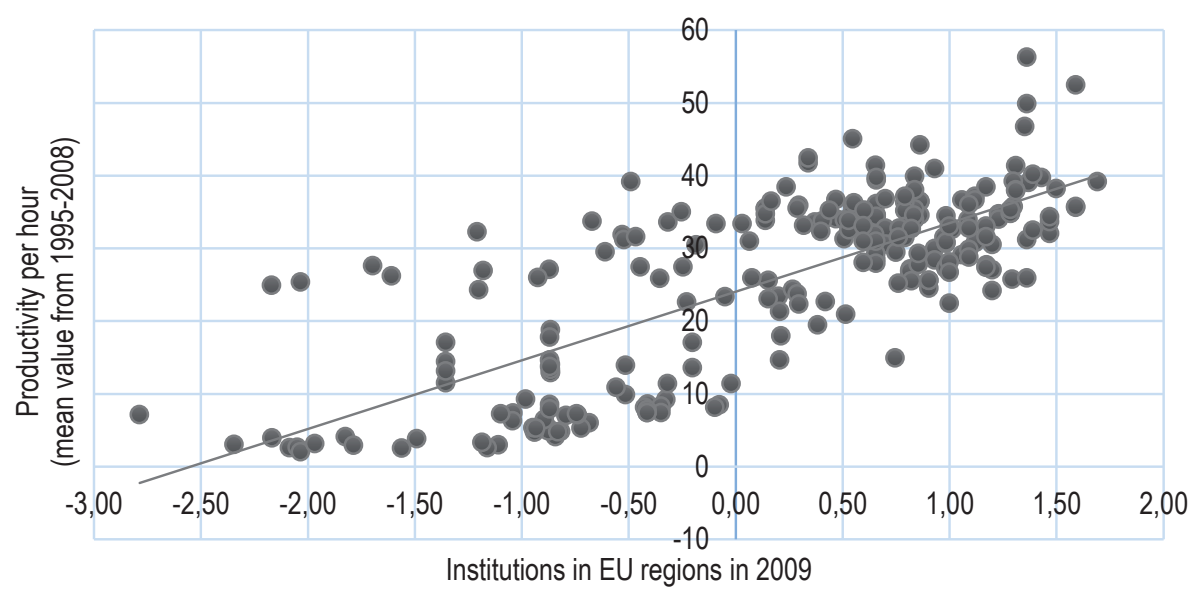

Figure 4. The institutional environment and mean value of labor productivity in EU regions

Source: own materials based on selected data: Quality of Government Institute 2010, http://qog.pol.gu.se/data/datadownloads/qogeuregionaldata and European Regional Database, Cambridge Econometrics, http://www.camecon.com/SubNational/SubNationalEurope/RegionalDatabase.aspx (03.08.2015).

\section{CONCLUSIONS}

The objective of the study was an attempt to define widely recognized institutions and to determine relations and mechanisms by which these institutions can affect the functioning of the economy. In addition, an analysis of the differentiation of institutions and labor productivity in the selected regions of the European Union was carried out.

The conducted analyzes showed that good institutional solutions expressed by protecting the property rights, lowering transaction costs, stimulating competition and improving the operational efficiency of the market mechanism, promote economic activity, innovation and directly contribute to the growth of labor productivity.

The analysis of the surveyed institutions in the examined regions of the European Union also revealed that in the group in question there are significant differences both between and within countries themselves. The countries where the institutions ranked the highest include Denmark, Sweden, Finland, the Netherlands and Luxembourg. In turn, institutions which occupy the bottom of the ranking are in Poland, Lithuania, Greece, Bulgaria and Romania. The largest domestic institutional differentiation was noted in Italy, Romania, France and Bulgaria. Similar trends were also observed in the area of labor productivity per hour in various regions of the EU. For the last twenty years 
this differentiation remained at relatively stable level. The fact that the regions with higher ratings of the institutions, also achieve higher hourly value of labor productivity, is also of vital importance. It may imply the existence of not only cause-effect relations but at least functional ones (coexistence).

Stressing the growing interest in institutions as potential factors that may have a significant impact on the economic performance of respective economies, it is worth noting here that conducted analyses and generated thereby results are of more "distinctive" rather than "certain" nature. However, they may constitute a good starting point for even more detailed and extensive research, including econometric ones dealing with relations that occur between the institutions and the functioning of the economy at regional level.

\section{BIBLIOGRAPHY}

Acemoglu D., Johnson S., Robinson J.A., Institutions as a fundamental cause of long-run growth, "Handbook of Economic Growth", Vol. 1, Part A/2005, http:// dx.doi.org/10.1016/s1574-0684(05)01006-3.

Acemoglu D., Johnson S., Robinson J.A., The colonial origins of comparative development: an empirical investigation, "American Economic Review", Vol. 91, No. 5/2001, http://dx.doi.org/10.1257/aer.91.5.1369.

Acemoglu D., Robinson J.A., De facto political power and institutional persistence, "American Economic Review", Vol. 96, No. 2/2006, http://dx.doi. org/10.1257/000282806777212549.

Acemoglu D., Robinson J.A., Why Nations Fail, Crown Business, New York: Cambridge University Press, 2012.

Amin A., An institutionalist perspective on regional development, "International Journal of Urban and Regional Research", Vol. 23, No. 2/1999, http://dx.doi. org/10.1111/1468-2427.00201.

Amin A., Thrift N., Globalization, Institutions and Regional Development in Europe, Oxford University Press, Oxford 1994.

Baumol W.J., Entrepreneurship: productive, unproductive and destructive, "Journal of Political Economy", Vol. 98, No. 5/1990, http://dx.doi.org/10.1086/261712.

Chakravarti A., Aid, Institutions and Development. New Approaches to Growth, Governance and Poverty, Edward Elgar Publishing, Cheltenham, UK, Northampton, MA USA 2005.

Charron N. et al., Measuring the quality of government and subnational variation, Quality of Government Institute, Department of Political Science, University of Gothenburg Sweden, Gothenburg 2010, http://ec.europa.eu/regional_policy/ sources/docgener/studies/pdf/2010_government_1.pdf (22.12.2015). 
Chong A., Calderon C., Causality and Feedback Between Institutional Measures and Economic Growth, "Economics and Politics", Vol. 12, No. 1/2000, http://dx.doi. org/10.1111/1468-0343.00069.

Ertur C., Le Gallo J., Baumont C., The European regional convergence process, 1980-1995: Do spatial regimes and spatial dependence matter?, "International Regional Science Review", Vol. 29, No. 1/2006, http://dx.doi.org/10.1177/0160017605279453.

Golejewska A., Kapitat ludzki, innowacje i instytucje a konkurencyjnośc regionów Europy Srodkowej i Wschodniej (Human capital, innovations and institutions versus the competitiveness of regions in Central and Eastern Europe), "Zeszyty Natolinskie", No. 49/2013.

Jarmołowicz W., Kuźmar S., Efektywność gospodarowania zasobami pracy w regionie na przyktadzie województwa wielkopolskiego w latach 2000-2012, "Studia i Prace WNEiZ US”, Vol. 35, No. 2/2014.

Krugman P.R., Geography and Trade, Cambridge MIT Press, Cambridge M.A, 1991. Krugman P.R., Increasing Returns and Economic Geography, "Journal of Political Economy", Vol. 99, No. 3/1991, http://dx.doi.org/10.1086/261763.

Kuźmar S., Pilc M., The Impact of Labor Market Institutions on Labor Market Performance in Transition Countries, "Ekonomista", No. 1/2015.

Lucas R., On the mechanics of economic development, "Journal of Monetary Economics", Vol. 22, No. 1/1988, http://dx.doi.org/10.1016/0304-3932(88)90168-7.

Magrini S., Regional (Di)Convergence, Handbook of Regional and Urban Economics, Amsterdam 2004, http://dx.doi.org/10.1016/s1574-0080(04)80019-1.

Miłaszewicz D., Jakośc instytucji a wzrost gospodarczy, "Studia i Prace Wydziału Nauk Ekonomicznych i Zarządzania”, No. 19/2011.

Monfort P., Convergence of EU regions. Measures and evolution, Directorate-General for Regional Policy Working Paper, No. 01/2008.

North C.D., Institutions, Institutional Change, and Economic Performance, Cambridge University Press, New York 1990.

Ostrom E., Challenges and Growth: The Development of the Interdisciplinary Field of Institutional Analysis, "Journal of Institutional Economics", Vol. 3, No. 03/2007, http://dx.doi.org/10.1017/s1744137407000719.

Rodríguez-Pose A., Do institutions matter for regional development?, "Regional Studies", Vol. 47, No. 7/2013, http://dx.doi.org/10.1080/00343404.2012.748978.

Rodrik D., Subramanian F., Trebbi F., Institutions rule: the primacy of institutions over geography and integration in economic development, "Journal of Economic Growth", Vol. 9, No. 2/2004, http://dx.doi.org/10.1023/b:joeg.0000031425.72248.85.

Romer S.M., Increasing returns and long-run growth, "Journal of Political Economy", Vol. 94, No. 5/1986, http://dx.doi.org/10.1086/261420.

Sautet F., The role of institutions in entrepreneurship: implications for development policy, "Mercatus Policy Series", Policy primer No. 1/2005.

Solow R.M., A contribution to the theory of economic growth, "Quarterly Journal of Economics”, Vol. 70, No. 1/1956, http://dx.doi.org/10.2307/1884513. 
Stankiewicz W., Ekonomia instytucjonalna. Narodziny i rozwój, Wydawnictwo Biura Badań Strategicznych Wyższej Szkoły Biznesu i Administracji, Warszawa 2004.

Storper M., Society, community and economic development, "Studies in Comparative International Development", No. 39/2005.

Streeck W., On the institutional conditions of diversified quality production, [in:] E. Metzner, K.W. Streec (eds), Beyond Keynesianism: Socio-Economics of Production and Full Employment, Elgar Publishing, Aldershot 1991.

Szarzec K., Państwo w gospodarce, Wydawnictwo PWN, Warszawa 2013.

Valeriani E., Peluso S., The Impact Of Institutional Quality On Economic Growth And Development: An Empirical Study, "Journal of Knowledge Management, Economics and Information Technology", No. 6/2011.

Vogit S., How (Not) to Measure Institutions, "Joint Discussion Paper Series in Economics", No. 37/2009.

World Bank, World Development Report 2002: Building Institutions for Markets, Oxford University Press, New York 2002. 